\title{
The eocrinoid Ascocystites Barrande (Echinodermata, Blastozoa) from the Middle Ordovician of central Portugal, with comments on the stratigraphy of the Brejo Fundeiro Formation
}

\author{
Timothy P. Young ${ }^{1}$ and Stephen K. Donovan ${ }^{2}$ \\ 'Department of Geology, University of Wales College of Cardiff, \\ P.O. Box 914, Cardiff CF1 3YE, Wales, United Kingdom \\ ${ }^{2}$ Department of Geology, University of the West Indies, Mona, Kingston 7, Jamaica
}

Date Received June 20, 1993

Date Accepted August 1, 1993

\begin{abstract}
The eocrinoid Ascocystites is recorded from the Middle Ordovician (Lower Llanvirn) Brejo Fundeiro Formation of the Dornes region, central Portugal. The Brejo Fundeiro Formation is a sequence of mudrocks overlying the "Armorican Quartzite" (Lower Ordovician, Arenig). Ascocystites was found in a decalcified concretion from a horizon close to the base of the formation. This genus has previously been recorded only from the Middle Ordovician of Bohemia and the Armorican Massif. All occurrences lie within the Gondwanan West European Platform.
\end{abstract}

L'éocrinoïde Ascocystites est reconnu dans la Formation de Brejo Fundeiro de l'Ordovicien moyen (Llanvirn inférieur) de la région de Darnes, dans le centre du Portugal. La Formation de Brejo Fundeiro est une séquence de mudrocks recouvrant la "Quartzite Armoricaine" (Ordovicien inférieur, Arenig). Ascocystites fut trouvé dans une concrétion décalcifiée d'un horizon près de la base de la formation. Ce genre était auparavant connu seulement de l'Ordovicien moyen de la Bohème et du massif armoricain. Toutes les occurences se situent dans la plate-forme de Gondwana de l'Europe de l'ouest.

[Traduit par la rédaction]

\section{INTRODUCTION}

The Lower Paleozoic echinoderms (mainly blastozoan pelmatozoans) of Portugal were documented by Delgado (1908, among others). However, these reports largely consist of lists of species, lacking illustrations and formal descriptions. Lower Paleozoic echinoderms of Portugal are, therefore, in need of detailed reanalysis. As a contribution to this study, the first occurrence of the eocrinoid genus Ascocystites in Portugal is recorded herein.

The described specimens are deposited in the British Museum (Natural History), London (BMNH). Eocrinoid terminology follows Ubaghs (1968). The protocol of open nomenclature follows Bengtson (1988).

\section{Stratigraphy}

The specimens are preserved in a decalcified concretion from the lower part of the Brejo Fundeiro Formation (Llanvirn, Middle Ordovician) of the Dornes region, central Portugal (Fig. 1). The Brejo Fundeiro Formation, informally erected by Cooper (1980), constitutes the local lower part of a midOrdovician succession dominated by mudrocks. This overlies the local development of the Arenig (Lower Ordovician) "Armorican Quartzite" facies. Indeed, the sandstone-dominated Arenig strata are overlain throughout the West European Platform (Young, 1990), including central Portugal, by mudstones of Llanvirn age (Romano et al., 1986; Young,
$1989,1990)$. This major change of facies is interpreted as the product of a relative rise of sea-level close to the Arenig/ Llanvirn boundary (Young, 1989; Fortey et al., 1990). The area in which the cystoid was found constitutes the type area for both the Serra do Brejo and Brejo Fundeiro formations.

The concretion was recovered from the debris on the surface of a forestry track at locality 1 (Fig. 1.1). Although not recovered in situ, the concretion is not considered to have been transported far, if at all. The point at which it was collected corresponds to a stratigraphic horizon approximately 10 to $20 \mathrm{~m}$ above the base of the Brejo Fundeiro Formation, but poor exposure and faulting have prevented closer determination of provenance. Sections along strike from locality 1 were examined, therefore, in an attempt to provide more information on the origin of the concretion.

Locality 2 (Fig. 1.2) presents a rather faulted and incomplete section through the upper part of the Serra do Brejo Formation and the lower part of the Brejo Fundeiro Formation. The actual contact between units is not seen, but approximately $12 \mathrm{~m}$ of the Brejo Fundeiro Formation is exposed below an ooidal ironstone (ironstone horizon ${ }^{\circ} 1$ of Young, 1989), with a $9 \mathrm{~m}$ gap in the section between these strata and the highest exposed Serra do Brejo Formation (Fig. 2). The ooidal ironstone overlies a coarsening-upward sequence of bedded siltstones. Discoidal concretions up to 300 $\mathrm{mm}$ in diameter form a horizon $2.7 \mathrm{~m}$ below the base of the ironstone. These concretions are decalcified and partly silicified, and the original carbonate mineralogy is unknown. The 

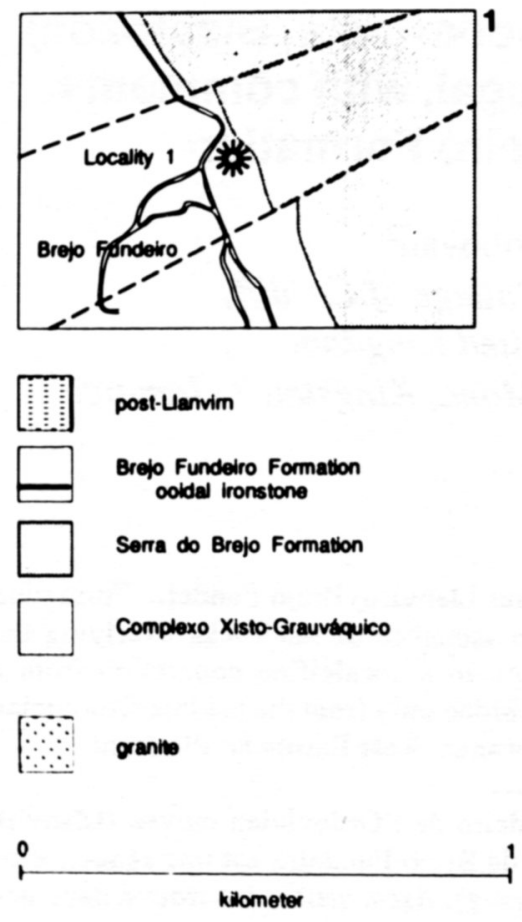
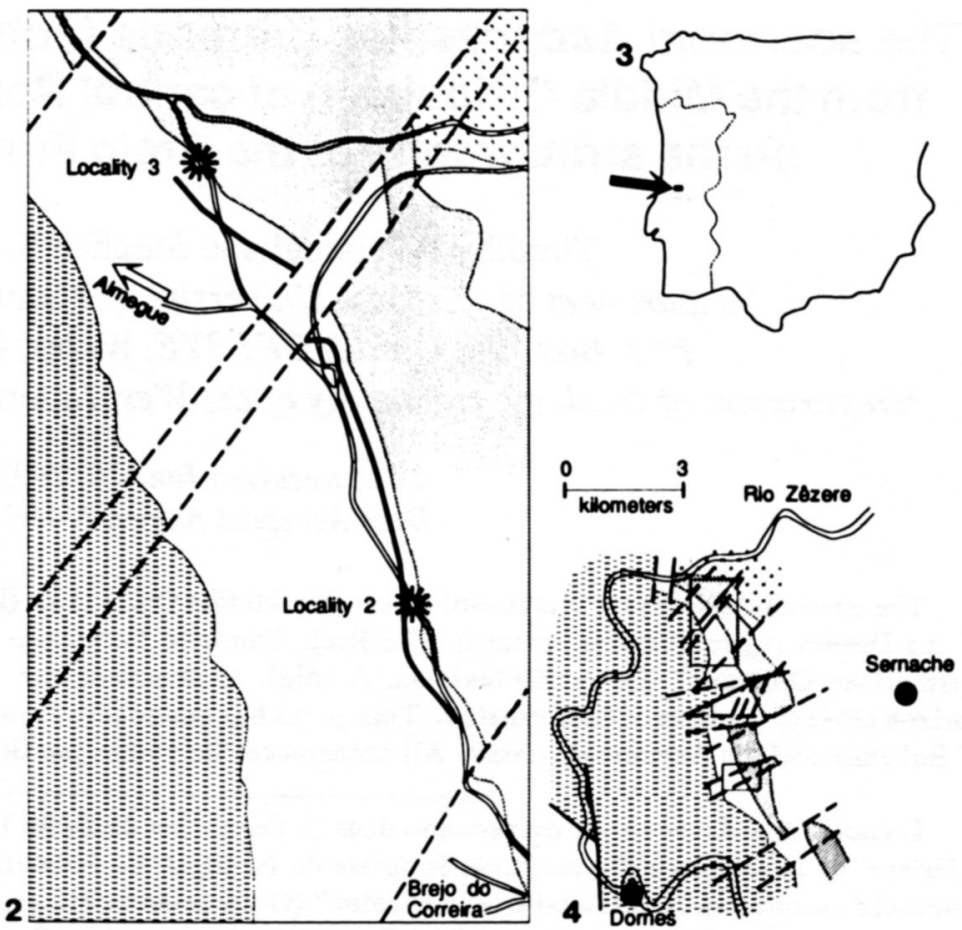

Fig. 1. Locality maps. (1) Locality 1 (starred), which yielded the specimens of Ascocystites sp. described herein. (2) Localities 2 and 3 (starred; see measured sections, Fig. 2). (3) Outline map of the Iberian Peninsula, showing the position of the Dornes region (arrowed). (4) Geological map of the Dornes region, showing the relationship between the areas shown in Figures 1.1 (upper box) and 1.2.

concretions contain a fauna that includes pendant didymograptids and asaphid trilobites. Concretions also occur up to $10 \mathrm{~m}$ above the ironstone, but these are invariably very hard, compact, dark nodules with cone-in-cone structures. It is almost certain that the horizon yielding the specimen described herein is that just below the ooidal limestone. Large carbonate concretions also occur within siltstones a similar distance beneath the same ironstone horizon at Postolonnec, Brittany.

Locality 3 (Figs 1.2,2) exposes a short length of section across the Serra do Brejo Formation/Brejo Fundeiro Formation boundary. The contact between the highest sandstone of the Serra do Brejo Formation and the lowest mudstone of the Brejo Fundeiro Formation is sharp. The highest sandstone has been eroded into bedforms with steep, locally overhanging sides, with an erosional relief of up to $200 \mathrm{~mm}$. The sandstone contains much fine-grained phosphatic material and resembles the uppermost bed of the "Armorican Quartzite" in the Buçaco syncline $50 \mathrm{~km}$ to the north (Romano et al., 1986). Fossils are not abundant in the lowest Brejo Fundeiro Formation, but pendant didymograptids occur within $1 \mathrm{~m}$ of the base, as they also do in the Buçaco syncline localities described by Romano et al. (1986).

Additional clarification of the local lithostratigraphy is necessary. Both the Serra do Brejo and Brejo Fundeiro formations are based on informal units proposed by Cooper (1980). The Serra do Brejo Formation was erected formally by Cooper and Romano (1982). A formal definition of the Brejo Fundeiro Formation has not been published, but it has been mentioned in papers by Romano (1982a, b), Cooper and Romano (1982), Young (1988, 1989, 1990), and Paris (1990). Romano (1982b) mentioned that the type section is $500 \mathrm{~m}$ south of Brejo Fundeiro and Young (1988) made this formation the lowest unit of the Cacemes Group. While a complete description of this unit is beyond the scope of this paper, it is considered relevant to describe and discuss the nature of the base of the formation in what has been indicated (Cooper and Romano, 1982) as the type area.

The unpublished description by Cooper (1980) of his 'type section' did not include a measured section of the base of the formation. Because of the great contrast in competence between the Serra do Brejo Formation (and its lateral equivalents) and the overlying mudstones, this contact is almost everywhere poorly exposed. In central Portugal, five sections across the contact have now been found in the Buçaco syncline (two described by Romano et al., 1986) and one in the Dornes area (locality 3 herein; Fig. 2). The base of the formation is not exposed in the area described by Romano (1982b) as the type area of the formation. Locality 3 of the present paper is less than $6 \mathrm{~km}$ north of the type area designated by Cooper (1980) and mentioned by Romano (1982b). It is therefore considered appropriate to formalize the basal stratotype for the formation at this locality. The base of the formation is taken as the sharp contact between the phosphatic sandstones and the overlying siltstones, as indicated above.

The top of the formation is coincident with the base of the Monte da Sombadeira Formation. This unit has also not been 


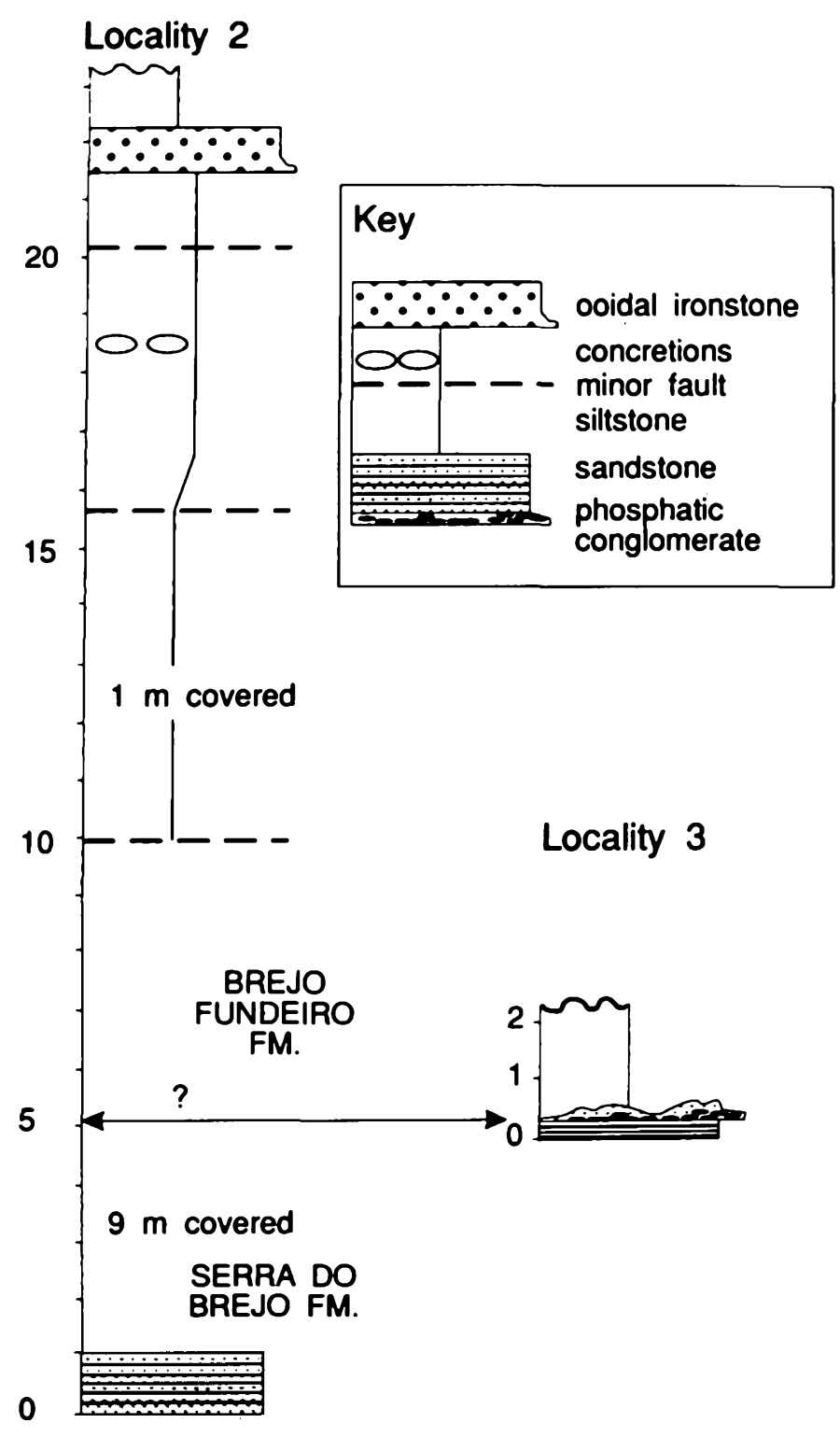

Fig 2. Measured sections of the upper Serra do Brejo and lower Brejo Fundeiro formations at localities 2 and 3 (see Fig. 1.2). Vertical scale in meters.

formally defined, but is now widely used. Its sedimentology was discussed by Brenchley et al. (1986), who illustrated several sections of the formation. The top of the Monte da Sombadeira Formation is formed by the base of the overlying siltstone unit defined by Young (1988) as the Fonte da Horta Formation.

The ooidal ironstone overlying the nodule-bearing bed is considered to be the same horizon as that in the Buçaco syncline further north, which in turn has been correlated with a similar unit in Brittany (Young, 1989, 1992). Paris (1981) placed the ironstone in Brittany within chitinozoan biozone 7. Biozone 6 is recorded from phosphatized clasts within the ironstone, and biozone 5 from beds beneath the nodulebearing horizon. The horizon with the nodules is thus within biozone 5 or 6. Paris (1990) has formalized his earlier zonal scheme, and beds correlated by Young $(1989,1992)$ with the nodule-bearing horizon at Dornes are attributed to the Cyathochitina calix Biozone (=Zones 5 and 6 of Paris, 1981). This biozone is interpreted as being equivalent to part of the Didymograptus (Didymograptus) artus Biozone of the Anglo-Welsh area (Lower Llanvirn; Fortey et al., 1991).

\section{Systematic Paleontology}

\section{Class Blastozoa Sprinkle, 1973}

Remarks: The Blastozoa were originally erected as a subphylum of the echinoderms by Sprinkle (1973, p. 56), but are best regarded as a class following the recognition of the Pelmatozoa and Eleutherozoa as natural groups (=subphyla) by Paul and Smith (1984).

\section{Group 'Eocrinoidea' Jaekel, 1918}

Remarks: The eocrinoids, given class status by Jaekel (1918; see also Broadhead, 1982), are a paraphyletic group (Paul, 1988). However, the term eocrinoid is used informally herein to designate a particular level of blastozoan organization (Paul and Smith, 1984).

\section{Family Ascocystitidae Ubaghs, 1968 Genus Ascocystites Barrande, 1887}

Type species: By original designation, Ascocystites drabowensis Barrande, 1887, p. 118, pls. 32, 33 (Bassler and Moodey, 1943, p. 132; Ubaghs, 1968, p. S483).

Other species: $A$. barrandei Jaekel, 1918; A.? cuneiformis Chauvel, 1941; A. micraster Barrande, 1887; Ascocystites sp.

Diagnosis: (Based on Ubaghs, 1968; Sprinkle, 1973; Paul, 1988). Column holomeric, heteromorphic with alternating larger and smaller discoid columnals, circular in section and tapering distally. Theca large, elongate, hexagonal in section and spindle-shaped. Theca comprised of numerous, larger or smaller, polygonal plates, not arranged in circlets, but with six principal columns of ossicles, sculptured by radiating ridges. No epispires, but radiating ridges are hollow grooves interiorly. Oral surface flattened, tegmen-like, with a central peristome, with five large, interradial oral and a variable number of radial adoral ossicles. Five curved ambulacra with brachioles arising by exotomous (on the left side only) to heterotomous branching. Twenty to thirty biserial brachioles, inserted on the outer edge of an oral plus adoral or of two adorals at edge of oral surface. Brachioles long and biserial. Cover plates on peristome and on adoral grooves. Positions of gonopore, hydropore and anus unknown.

Range: Middle Ordovician of Bohemia, France (Armorican Massif) and Portugal. 


\section{Ascocystites sp.}

Figures 3, 4

Material: Natural History Museum (BMNH), London, EE $3205 a, b$, a decalcified concretion containing at least three part and counterpart external moulds of Ascocystites sp., numbered EE 3205 (1)-(3).

Occurrence: Collected as a loose block probably derived from a horizon of decalcified concretions near the base of the Brejo Fundeiro Formation, Dornes region, central Portugal (Figs. 1, 2), Lower Llanvirn (Middle Ordovician). See discussion above.

Description: Distal termination of column not preserved (but see Nestler, 1987). BMNH EE 3205(1) retains proximal 7 $\mathrm{mm}$ of column which curves through $90^{\circ}$. Columnal holomeric, circular in section and tapering distally immediately beneath the theca. Heteromorphic N1 (sensu Webster, 1974), comprised of alternating lower and higher columnals, with contrast in heights decreasing distally (EE 3205(1)), or without a heteromorphic alternation of columnals (EE 3205(3)). Articular facet not seen.

Theca flattened (=crushed after burial), conical and high. Plating sometimes indistinct. Six rays, each consisting of a uniserial sequence of plates, each ray with a prominent, median ridge. Lowermost plates of each ray high, narrowest at base, widening adorally, polygonal (pentagonal?) in outline and forming a circlet at the base of the theca. Other plates of ray series broad, high, polygonal, and arranged in columns, but not circlets. Rays separated by polygonal interradial plates. Plates of theca bear a fine, ridged sculpture. Epispires absent. Oral surface not preserved.

Brachioles slender, biserial, comprised of moderately high plates. Adoral groove concealed by cover plates.

Discussion: This is the first record of Ascocystites from the Iberian Peninsula. However, none of the available thecae is sufficiently well-preserved for them to be included within any of the nominal species within this genus. The closest paleogeographic occurrence of Ascocystites to Dornes is A.? cuneiformis Chauvel from the Armorican Massif (Fig. 5). However, this is too poorly known for a comparison with the Dornes species (Chauvel, 1941, p. 118, 119, fig. 47). Indeed, Ascocystites would benefit from a thorough revision based on all available material in order to delineate fully the differences between species and the structure of the theca.

Delgado (1908) tabulated Ordovician faunas, including echinoderms, from various Portugese sequences. Moderately diverse pelmatozoan faunas (principally blastozoans with

Fig. 3. Ascocystites sp. (1) BMNH EE 3205a. Large theca is EE 3205(1) (brachioles indicated by open arrow), with EE 3205(2), a smaller theca, indicated by a closed arrow. (2) BMNH EE 3205b. Latex casts of part and counterpart external moulds whitened with ammonium chloride. Both $\times 3$.
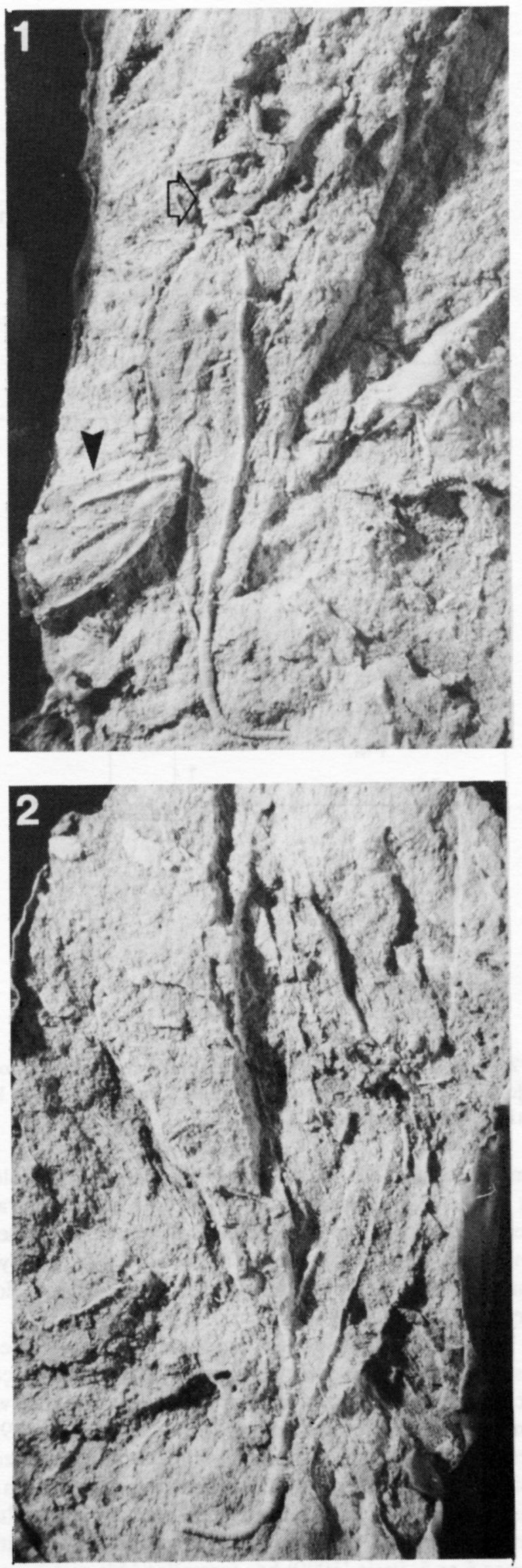


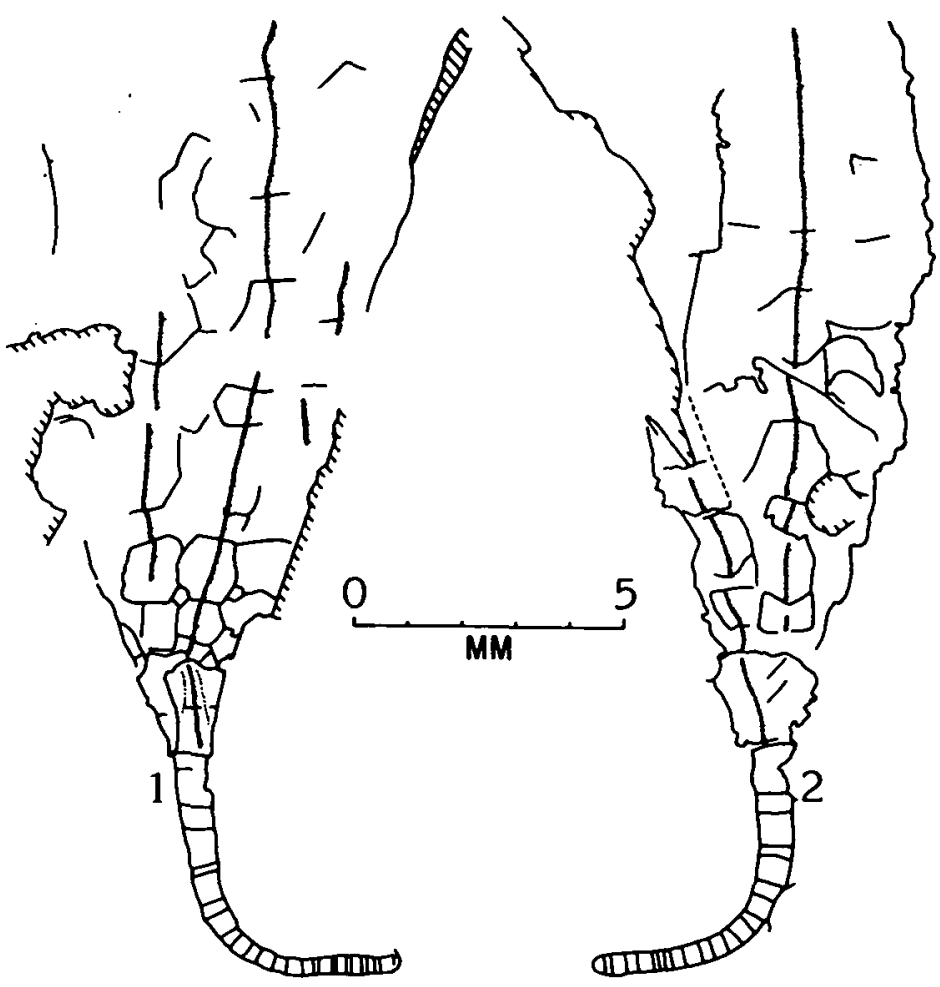

Fig. 4. Ascocystites sp., BMNH EE 3205(1), column and lower part of theca. (1) BMNH EE 3205a. (2) BMNH EE 3205b. Camera lucida drawings of latex casts taken from part and counterpart external moulds.

common crinoid(?) columnals) are known from the Lower Caradoc of Amêndoa and the Ashgill of Buçaco (see maps in Romano, 1982a; Young, 1990). The Dornes region is stratigraphically similar to the Amênoda area, from which Delgado (1908) only recorded the aristocystitid diploporite Calix murchisoni Verneuil and Barrande in the Llanvirn. Delgado recorded no echinoderms from the Ordovician of Dornes.

The Dornes area forms part of the West European Platform of Young (1990), a region of thin Ordovician shelf sequences (=Variscan Massifs) including the Centro-Iberian/Armorican region, the Catalan region, the Ossa Morena Zone, Thuringia, Bohemia, and the Carnic Alps. This region was a stable cratonic block during the Ordovician. The known distribution of Ascocystites lies entirely within the limits of this platform region, with species having been described from Bohemia, Armorica and now Dornes. The West European Platform is considered to have formed part of Gondwana during the Ordovician (Young, 1990), based on paleontological and tectonic evidence, and all occurrences of this genus lie between about $30^{\circ} \mathrm{S}$ and $60^{\circ} \mathrm{S}$ paleolatitude (Fig. 5).

\section{Acknowledgements}

S.K.D. thanks C.R.C. Paul for identifying these specimens and for bringing Delgado's contributions to the study of Portugese cystoids to his attention. The photographs in Figure 3 were taken using a photomicroscope made available at

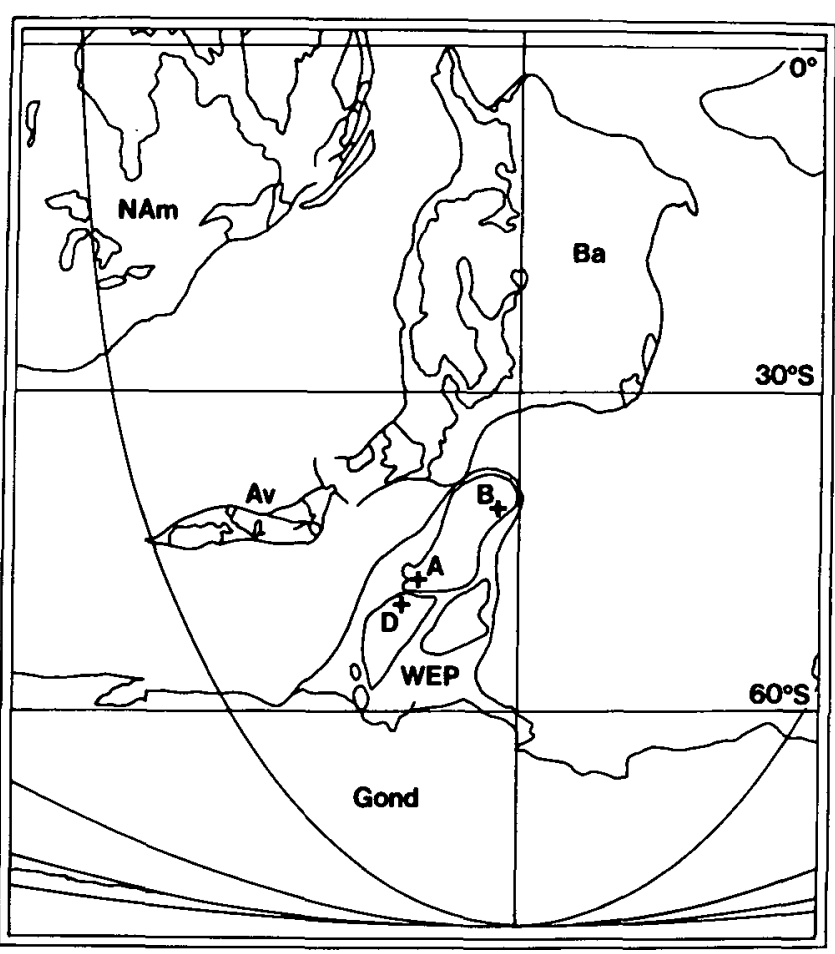

Fig. 5. Paleogeographic distribution of the eocrinoid genus Ascocystites during the Middle Ordovician (base map redrawn after Young, 1990, fig. 7). Key: $+=$ Ascocystites localities; $\mathbf{A}=$ Armorica; $\mathbf{B}=$ Bohemia; $\mathbf{D}=$ Dornes; $\mathbf{A v}=$ Avalonia; $\mathbf{B a}=$ Baltica; Gond = Gondwana; NAm = North America; WEP = West European Platform. Lines of longitude and latitude shown.

the BMNH by A.B. Smith. This research was completed during the periods of a visiting scholarship from the Thomas Dee fund of the Field Museum of Natural History, Chicago, and a Short Term Visitor grant at the National Museum of Natural History, Smithsonian Institution, Washington, D.C., both to S.K.D., which are gratefully acknowledged. Comments on an earlier version of this paper by C.R.C. Paul and J. Sprinkle are gratefully acknowledged.

Barrande, J. 1887. Systême Silurien du Centre de la Bohême, 7(1), Cystidées. Gerhard, Leipzig and Rivná̌, Prague, 233 p.

BAssLer, R.S. and Moodey, M.W. 1943. Bibliographic and faunal index of Paleozoic pelmatozoan echinoderms. Geological Society of America, Special Papers 45, 734 p.

Benotson, P. 1988. Open nomenclature. Palaeontology, 31, pp. 223-227.

Brenchley, P.J., Romano, M., and GutiérRez-MarCo, J.C. 1986. Proximal and distal cross-stratified facies on a wide Ordovician shelf in Iberia. In Shelf Sands and Sandstones. Edited by R.J. Knight and J.R. McClean. Canadian Society of Petroleum Geologists, Memoir 11, pp. 241-255.

Brondhead, T.W. 1982. Reappraisal of class Eocrinoidea (Echinodermata). In Echinoderms: Proceedings of the International Conference, Tampa Bay, 14 to 17 September, 1981. Edited by J.M. Lawrence. Balkema, Rotterdam, pp. 125-131.

Chauvel, J. 1941 (for 1939). Recherches sur les Cystoïdes et les Carpoïdes Armoricains. Mémoires de la Société Géologique et Minéralogique de Bretagne, 5, 286 p. 
CoOper, A.H. 1980. The stratigraphy and palaeontology of the Ordovician to Devonian rocks of the area north of Dornes (near Figueiro dos Vinhos), central Portugal. Unpublished Ph.D. dissertation, University of Sheffield, England, 429 p.

Cooper, A.H. and Romano, M. 1982. The Lower Ordovician stratigraphy of the Dornes - Figuiero dos Vinhos area, central Portugal, with descriptions of Merostomichnites ichnosp. and Rosselia socialis; two previously unrecorded trace fossils. Communicações dos Serviços Geológicos de Portugal, 68, pp. 73-82.

Deloado, J.F.N. 1908. Système silurique du Portugal. Étude de stratigraphie paléontologique. Memorias et Communicações dos Serviços geológicos de Portugal, 245 p.

Fortey, R.A., BeCkLY, A.J., and Rushton, A.W.A. 1990. International correlation of the base of the Llanvirn Series, Ordovician System. Newsletters in Stratigraphy, 23, pp. 119-142.

Fortey, R.A., Bassett, M.G., Harper, D.A.T., Hughes, R.A., Inoham, J.K., Molyneux, S.G., OWen, A.W., OWens, R.M., Rushton, A.W.A., and Sheldon, P.R. 1991. Progress and problems in the selection of stratotypes for the bases of series in the Ordovician System of the historical type area in the U.K. In Advances in Ordovician Geology. Edited by C.R. Barnes and S.H. Williams. Geological Survey of Canada, Paper 90-9, pp. 5-25.

Jaek el, O. 1918. Phylogenie und System der Pelmatozoen. Paläontologische Zeitschrift, 3, pp. 1-128.

Nestler, H. 1987. Neuuntersuchung des Originals zu Jaekels "Wurzelblase von Ascocystites". Zeitschrift für Geologische Wissenschaften, 15, pp. 769-771.

Paris, F. 1981. Les chitinozoaires dans le Paléozoique du sudouest de l'Europe. Mémoire de la Société Géologique et Minéralogique de Bretagne, 26, 412 p.

1990. The Ordovician chitinozoan biozones of the Northern Gondwana Domain. Review of Palaeobotany and Palynology, 66, pp. 181-209.

PAUL, C.R.C. 1988. The phylogeny of the cystoids. In Echinoderm Phylogeny and Evolutionary Biology. Edited by C.R.C. Paul and A.B. Smith. Clarendon Press, Oxford, pp. 199-213.

PAUL, C.R.C. and Smith, A.B. 1984. The early radiation and phylogeny of echinoderms. Biological Reviews, 59, pp. $443-481$.
Romano, M. 1982a. The Ordovician biostratigraphy of Portugal - a review with new data and re-appraisal. Geological Journal, 17, pp. 89-110.

1982b. Portugal. In The Ordovician System in southwestern Europe (France, Spain, Portugal): correlation chart and explanatory notes. Edited by W. Hamman, M. Robardet and M. Romano. International Union of Geological Sciences, Publication 11, pp. 36-40.

Romano, M., Brenchley, P.J., and McDougall, N.D. 1986. New information concerning the age of the beds immediately overlying the Armorican Quartzite in central Portugal. Géobios, 19, pp. 421-433.

SPRINKLER, J. 1973. Morphology and evolution of blastozoan echinoderms. Special Publication, Museum of Comparative Zoology, Harvard University, Cambridge, Massachusetts, $283 \mathrm{p}$.

Uвлонs, G. 1968. Eocrinoidea. In Treatise on Invertebrate Paleontology, Part S, Echinodermata 1(2). Edited by R.C. Moore. Geological Society of America and University of Kansas Press, New York and Lawrence, pp. S455-S495.

Webster, G.D. 1974. Crinoid pluricolumnal noditaxis patterns. Journal of Paleontology, 48, pp. 1283-1288.

Youno, T.P. 1988. The lithostratigraphy of the Upper Ordovician of central Portugal. Journal of the Geological Society, London, 145 , pp. $377-392$.

1989. Eustatically controlled ooidal ironstone deposition: facies relationships of the Ordovician open-shelf ironstones of western Europe. In Phanerozoic ironstones. Edited by T.P. Young and W.E.G. Taylor. Geological Society, Special Publication 46, pp. 51-63.

1990. Ordovician sedimentary facies and faunas of southwest Europe: palaeogeographic and tectonic implications. In Palaeozoic Palaeogeography and Biogeography. Edited by W.S. McKerrow and C.R. Scotese. Geological Society, Memoir 12, pp. 419-428.

1992. Ooidal ironstones from Ordovician Gondwana: a review. Palaeogeography, Palaeoclimatology, Palaeoecology. 99. pp. 321-347. 